Matematikai Közlemények

VII. kötet, 2019

doi:10.20312/dim.2019.05

\title{
Kettős Gauss függvény alkalmazása
}

\author{
Csanády Viktória \\ SOE Matematikai Intézet \\ csanady.viktoria@uni-sopron.hu
}

\begin{abstract}
ÖSSZEFOGLALÓ. Az időbeli folyamatok jellemzése esetén gyakran a folyamat tendenciáját vizsgálva szükségünk lehet bonyolultabb matematikai modellek alkalmazására. A számítógépes statisztikai programok által felkínált alap modellek viszont erre nem adnak kielégítő választ, a felhasználónak kell a speciális modellt megtalálni, majd a gép adta lehetőség révén alkalmazni. Az alábbiakban két speciális kettős Gauss függvény kerül bemutatásra, annak rugalmasságát kiemelve, gyakorlati példákon illusztrálva.
\end{abstract}

ABSTRACT. To describe tendencies in time series processes we often need to apply complex mathematical models. The basic models offered by statistical computer programmes are usually not applicable, so the user must find the special model, apply it and exploit the computers' potentials. We present two special double-Gaussian functions below, stress their flexibilities through practical examples.

\section{Bevezetés}

Az egyes időfüggő folyamatok jellemzése során, amikor azok, nem mutatnak határozott tendenciát menetükben (monoton növekedés ill. csökkenés), gyakran csak a mérési pontok összekötésére hagyatkoznak ami persze egy meglehetősen primitív megoldás, nem beszélve arról, hogy a föbb matematikai jellemzők ezáltal nem vállnak ismerté. Ilyen esetekben, ha mégis modellillesztésre kerül sor, akkor az alkalmasnak tünő modell általában - amit használnak - egy magasabb fokszámú polinom függvény. Ez a függvény persze számos előírható és elvárható kritériumnak nem tesz eleget, továbbá az illesztésnél szükséges kezdőértékek megadása problémás, olykor sok időt és energiát felemésztő feladat. Az említett kritériumok közül a legkézenfekvőbb a végtelenekben történő viselkedése a polinom függvénynek, ami a vizsgált időbeli folyamatokra egyáltalán nem jellemző, így az alkalmasság megkérdőjelezhető. Az említett folyamatok esetében egyszerübb a helyzet akkor, amikor lokális szélsőértékkel nem, vagy csak egy ilyen jellemző ponttal bír a leírandó pontsorozat. Ezekben az esetekben általában jól alkalmazhatók az un. telítési függvények un. életfüggvények és ezek lineáris kombinációi, bonyolultabb esetekben szuperponált modelljei. Ennek fő indokai a függvények kedvező tulajdonságaiból fakadnak, így a zérushelyből történő indíthatóságból, a függvény korlátosságából illetve aszimptotikus tulajdonságából. Azokban az esetekben viszont, amikor a folyamatot jellemző adatsor több szélsőértékkel bír, inflexiós pontok megléte feltételezhető, akkor az említett modellek már nem alkalmasak a folyamat jellemzésére. Ez az illesztési probléma ösztönözte a gondolatot újabb összetett modellek létrehozására, melyek több szélsőérték esetén is működőképes rugalmas modellek, melyekből igény esetén számíthatók a matematikai jellemzök. Az alábbiakban bemutatásra kerülnek az összetett modellek illetve azok alkalmazása két erdészeti vonatkozásban, a felhasznált adatok a Központi Statisztikai Hivatal adatbázisából származnak. 
A vizsgálat tárgya:

- az 1996-2017 éves időszakban évenként kitermelt tölgy, nyár és akác fa mennyiségének időbeli változása. 1. táblázat: Kitermelt faanyag.

- az 1995/1996-2016/2017 időszak évenkénti fásítás-erdőtelepítés mértékének időbeli változása. 2. táblázat: Erdőtelepítés.

A vizsgált adathalmazok és az alkalmazott modellek:

A lehetséges reprodukálhatóság végett megadásra kerülnek a vizsgált adatsorok.

\begin{tabular}{|c|c|c|c|c|}
\hline \multirow{2}{*}{} & \multicolumn{4}{|c|}{ FAKITERMELÉS $1000 \mathrm{~m}^{3}$ /év } \\
\cline { 2 - 5 } & $\begin{array}{c}\text { Év } \\
\text { (VAR1) }\end{array}$ & $\begin{array}{c}\text { TÖLGY } \\
\text { (VAR2) }\end{array}$ & $\begin{array}{c}\text { NYÁR } \\
\text { (VAR3) }\end{array}$ & $\begin{array}{c}\text { AKÁC } \\
\text { (VAR4) }\end{array}$ \\
\hline 1 & 1996 & 980 & 1252 & 1370 \\
\hline 2 & 1997 & 1009 & 1188 & 1331 \\
\hline 3 & 1998 & 1033 & 1207 & 1266 \\
\hline 4 & 1999 & 1104 & 1170 & 1344 \\
\hline 5 & 2000 & 1184 & 1069 & 1496 \\
\hline 6 & 2001 & 1158 & 1090 & 1425 \\
\hline 7 & 2002 & 1161 & 976 & 1480 \\
\hline 8 & 2003 & 1133 & 921 & 1527 \\
\hline 9 & 2004 & 1119 & 933 & 1462 \\
\hline 10 & 2005 & 1188 & 883 & 1401 \\
\hline 11 & 2006 & 1157 & 898 & 1351 \\
\hline 12 & 2007 & 1189 & 875 & 1206 \\
\hline 13 & 2008 & 1166 & 921 & 1427 \\
\hline 14 & 2009 & 1052 & 942 & 1480 \\
\hline 15 & 2010 & 1102 & 980 & 1628 \\
\hline 16 & 2011 & 1104 & 1212 & 1857 \\
\hline 17 & 2012 & 1055 & 1113 & 1793 \\
\hline 18 & 2013 & 1039 & 1115 & 1745 \\
\hline 19 & 2014 & 941 & 1100 & 1541 \\
\hline 20 & 2015 & 941 & 1072 & 1488 \\
\hline 21 & 2016 & 938 & 1071 & 1429 \\
\hline 22 & 2017 & 898 & 1020 & 1488 \\
\hline
\end{tabular}

1. táblázat. Kitermelt faanyag 


\begin{tabular}{|c|c|c|c|c|}
\hline & \multicolumn{4}{|c|}{ Erdőtelepítés hektár/év } \\
\cline { 2 - 5 } & $\begin{array}{c}\text { TÉNY } \\
\text { IDÖSZAK }\end{array}$ & ÉV & $\begin{array}{c}\text { ELSÖ } \\
\text { TELEPÍTÉS } \\
\text { (VAR2) }\end{array}$ & $\begin{array}{c}\text { ÖSSZ } \\
\text { TELEPÍTÉS } \\
\text { (VAR3) }\end{array}$ \\
\hline 1 & $1995 / 96$ & 1995 & 6610 & 7804 \\
\hline 2 & $1996 / 97$ & 1996 & 8289 & 9742 \\
\hline 3 & $1997 / 98$ & 1997 & 8183 & 9795 \\
\hline 4 & $1998 / 99$ & 1998 & 8661 & 9858 \\
\hline 5 & $1999 / 00$ & 1999 & 9790 & 10842 \\
\hline 6 & $2000 / 01$ & 2000 & 13150 & 15516 \\
\hline 7 & $2001 / 02$ & 2001 & 14830 & 17169 \\
\hline 8 & $2002 / 03$ & 2002 & 12015 & 15028 \\
\hline 9 & $2003 / 04$ & 2003 & 7574 & 11581 \\
\hline 10 & $2004 / 05$ & 2004 & 7657 & 9439 \\
\hline 11 & $2005 / 06$ & 2005 & 13989 & 15008 \\
\hline 12 & $2006 / 07$ & 2006 & 18948 & 20289 \\
\hline 13 & $2007 / 08$ & 2007 & 7332 & 9441 \\
\hline 14 & $2008 / 09$ & 2008 & 5168 & 6303 \\
\hline 15 & $2009 / 10$ & 2009 & 5096 & 5960 \\
\hline 16 & $2010 / 11$ & 2010 & 2803 & 3461 \\
\hline 17 & $2011 / 12$ & 2011 & 4537 & 5009 \\
\hline 18 & $2012 / 13$ & 2012 & 2530 & 3250 \\
\hline 19 & $2013 / 14$ & 2013 & 1287 & 1599 \\
\hline 20 & $2014 / 15$ & 2014 & 318 & 452 \\
\hline 21 & $2015 / 16$ & 2015 & 158 & 300 \\
\hline 22 & $2016 / 17$ & 2016 & 626 & 694 \\
\hline
\end{tabular}

2. táblázat. Erdőtelepítés

Az alkalmazott regressziós modellek:

- Két Gauss függvény kompozíciója (GAUÉGAU)

- matematikai alakja:

$$
y=\frac{b_{6}}{e^{\left(b_{5}\left(x-b_{4}\right)\right)^{2}}}+\frac{b_{3}}{e^{\left(b_{2}\left(x-b_{1}\right)\right)^{2}}}+b_{0}
$$

- számítógépes alak:

$$
\operatorname{var} 2=b 6 / \exp ((b 5 *(\operatorname{var} 1-1 * b 4)) \wedge 2)+b 3 / \exp \left((b 2 *(\operatorname{var} 1-1 * b 1))^{\wedge} 2\right)+b 0 .
$$

Kezdőérték választás általános (2 maximum vagy minimum) esetben az adatsor értékei alapján:

\footnotetext{
b6=var 2 elsö max. - var 2 min. vagy b6=var2 2 elsö min. - var 2 max.

b3=var $2_{\text {másod. max. }}-\mathrm{var} 2$ min. vagy $\mathrm{b} 3=\mathrm{var} 2$ másod. min. $-\mathrm{var} 2 \max$.

b4=var1 első max. vagy var1 $1_{\text {első min. }}$

b1=var $1_{\text {másod. max. }}$ vagy $\operatorname{var} 1_{\text {másod. min. }}$
} 


$$
\begin{aligned}
& \text { b5 0,05 } \\
& \text { b2 0,05 } \\
& \text { b0 }=\text { var } 2 \text { min. }
\end{aligned}
$$

- Két abszolútértékes módosított Gauss függvény kompozíciója (ABGAUÉABGAU)

- matematikai alakja:

$$
y=\frac{b_{8}}{e^{\left(b_{7}\left|x-b_{6}\right|\right)^{b_{5}}}}+\frac{b_{4}}{e^{\left(b_{3}\left|x-b_{2}\right|\right)^{b_{1}}}}+b_{0}
$$

- számítógépes alak:

$\left.\left.\operatorname{var} 2=\mathrm{b} 8 / \exp ((\mathrm{b} 7 *(\operatorname{abs}(\operatorname{var} 1-1 * \mathrm{~b} 6))))^{\wedge} \mathrm{b} 5\right)+\mathrm{b} 4 / \exp ((\mathrm{b} 3 *(\operatorname{abs}(\operatorname{var} 1-1 * \mathrm{~b} 2))))^{\wedge} \mathrm{b} 1\right)+\mathrm{b} 0$.

Kezdőérték választás általános (2 maximum vagy minimum) esetben az adatsor értékei alapján:

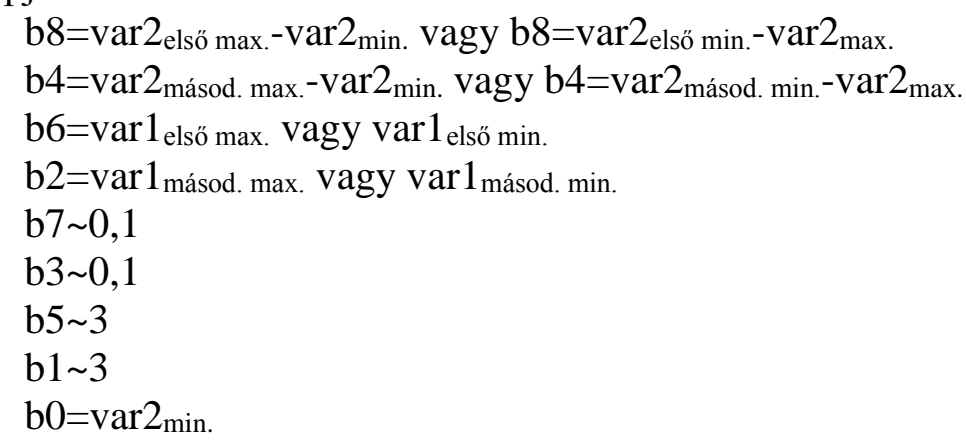

A modellek rövid jellemzése:

Az alkalmazott GAUÉGAU két transzformált Gauss függvény összegéből áll egy függőleges eltolással, ez adja meg a két szélsőérték létezésének feltételét továbbá a lehetséges asszimetriát. Az ABGAUÉABGAU függvény esetében a kitevő kitevője nem kettő, tetszőleges érték lehet, ami magával vonja az abszolútérték szükségességét. Az említett tetszőleges kitevő kitevője a modell rugalmaságát lényegesen növeli, akár törési pont is elöfordulhat a szélsőértékek mellett a modellben.

Első esetben 7, második esetben 9 paraméter befolyásolja a függvény alakját, ezen értékek kezdőértékeinek megadása viszont a már említett módokon könnyüszerrel megadható a pontsorozat ismeretében.

\section{Számított eredmények, kiértékelés}

\subsection{A fakitermelési adatsorok regressziós eredményei}

Mind a három fa faj esetén elsőként az ABGAUÉABGAU alkalmazás eredményeit tüntetjük fel majd közvetlen utána a GAUÉGAU eredményeit illetve azok grafikus repezentációját. 


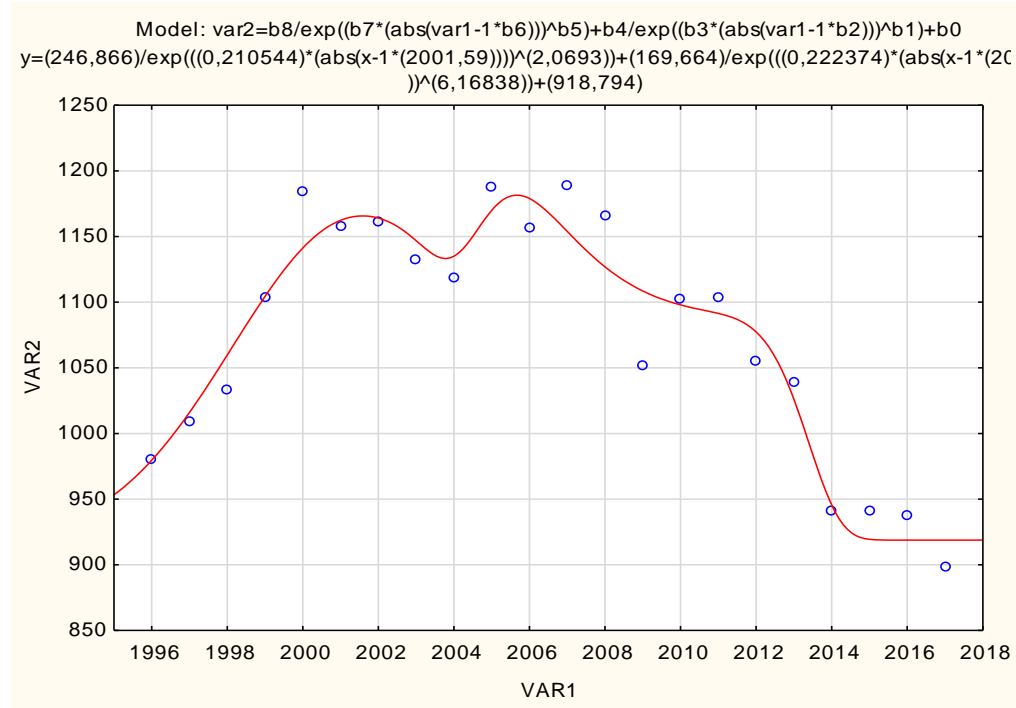

1. ábra. Tölgy ABGAUÉABGAU

\begin{tabular}{|c|c|c|c|c|c|c|c|c|c|}
\hline \multirow[b]{2}{*}{$\mathrm{N}=22$} & \multicolumn{9}{|c|}{$\begin{array}{l}\left.\text { Model: var2=b8/exp }\left(\left(\mathrm{b} 7^{*}\left(\mathrm{abs}\left(\mathrm{var} 1-1^{*} \mathrm{~b} 6\right)\right)\right)\right)^{\wedge} \mathrm{b} 5\right)+\mathrm{b} 4 / \exp \left(\left(\mathrm{b} 3^{*}(\mathrm{a} \ldots . .(\text { Tölgy })\right.\right. \\
\text { Dep. var: VAR2 Loss: (OBS-PRED)**2 } \\
\text { Final loss: } 11954,830685 \mathrm{R}=, 96584 \text { Variance explained: } 93,285 \%\end{array}$} \\
\hline & b8 & b7 & b6 & b5 & b4 & b3 & b2 & b1 & b0 \\
\hline Estimate & 246,8658 & 0,210544 & 2001,592 & 2,069304 & 169,6643 & 0,222374 & 2009,035 & 6,168376 & 918,7937 \\
\hline
\end{tabular}

3. táblázat. Tölgy ABGAUÉABGAU

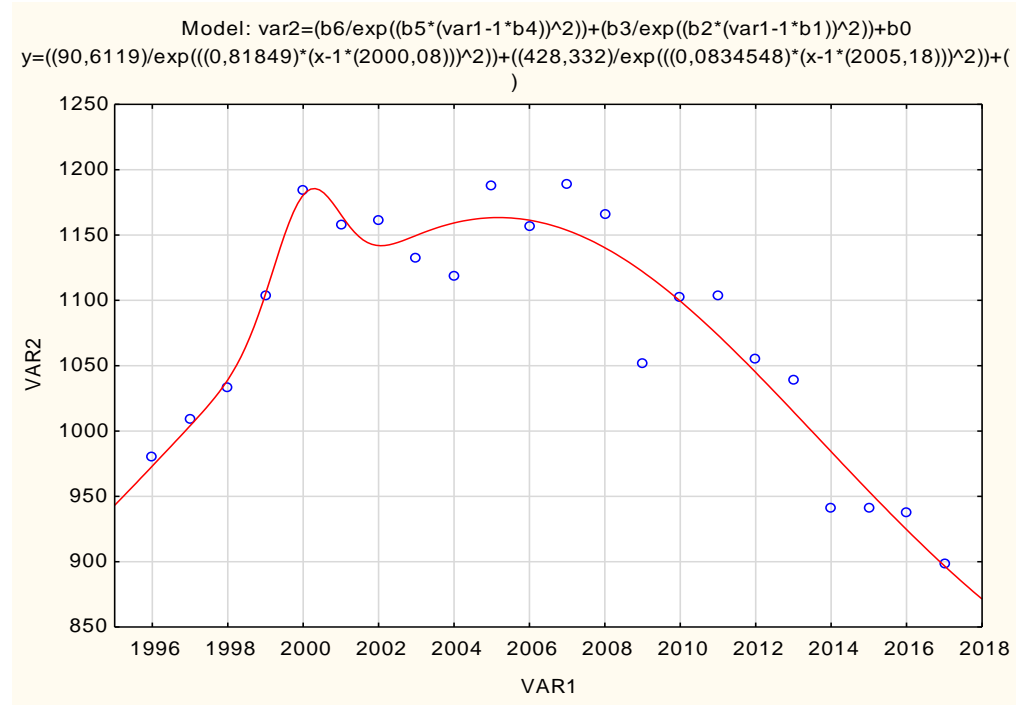

2. ábra. Tölgy GAUÉGAU

\begin{tabular}{|c|c|c|c|c|c|c|c|}
\hline \multirow[b]{2}{*}{$\mathrm{N}=22$} & \multicolumn{7}{|c|}{$\begin{array}{l}\text { Model: var2 }=\left(\mathrm{b} 6 / \exp \left(\left(\mathrm{b} 5^{*}\left(\operatorname{var} 1-1^{*} \mathrm{~b} 4\right)\right)^{\wedge} 2\right)\right)+\left(\mathrm{b} 3 / \exp \left(\left(\mathrm{b} 2^{*}(\operatorname{var} 1 \ldots(\text { Tölgy })\right.\right.\right. \\
\text { Dep. var: VAR2 Loss: }(\text { OBS-PRED })^{* * 2} \\
\text { Final loss: } 13732,520756 \mathrm{R}=, 96066 \text { Variance explained: } 92,286 \%\end{array}$} \\
\hline & \begin{tabular}{|l|}
$\mathrm{b} 6$ \\
\end{tabular} & b5 & b4 & b3 & $\mathrm{b} 2$ & $\mathrm{~b} 1$ & b0 \\
\hline Estimate & 90,61191 & 0,81849 । & 2000,071 & 428,332 & $0,08345 !$ & 2005,18 & 735,043 \\
\hline
\end{tabular}

4. táblázat. Tölgy GAUÉGAU 
Model: $\operatorname{var} 3=b 8 / \exp \left(\left(b 7^{*}\left(a b s\left(\operatorname{var} 1-1^{*} b 6\right)\right)\right)^{\wedge} b 5\right)+b 4 / \exp \left(\left(b 3^{*}\left(a b s\left(\operatorname{var} 1-1^{*} b 2\right)\right)\right)^{\wedge} \mathrm{b} 1\right)+b 0$ $\mathrm{y}=(267,511) / \exp \left(\left((0,280588)^{\star}\left(\operatorname{abs}\left(\mathrm{x}-1^{\star}(1997,51)\right)\right)\right)^{\wedge}(2,72306)\right)+(184,438) / \exp \left(\left((0,260717)^{\star}\left(\operatorname{abs}\left(\mathrm{x}-1^{\star}(\varepsilon\right.\right.\right.\right.$

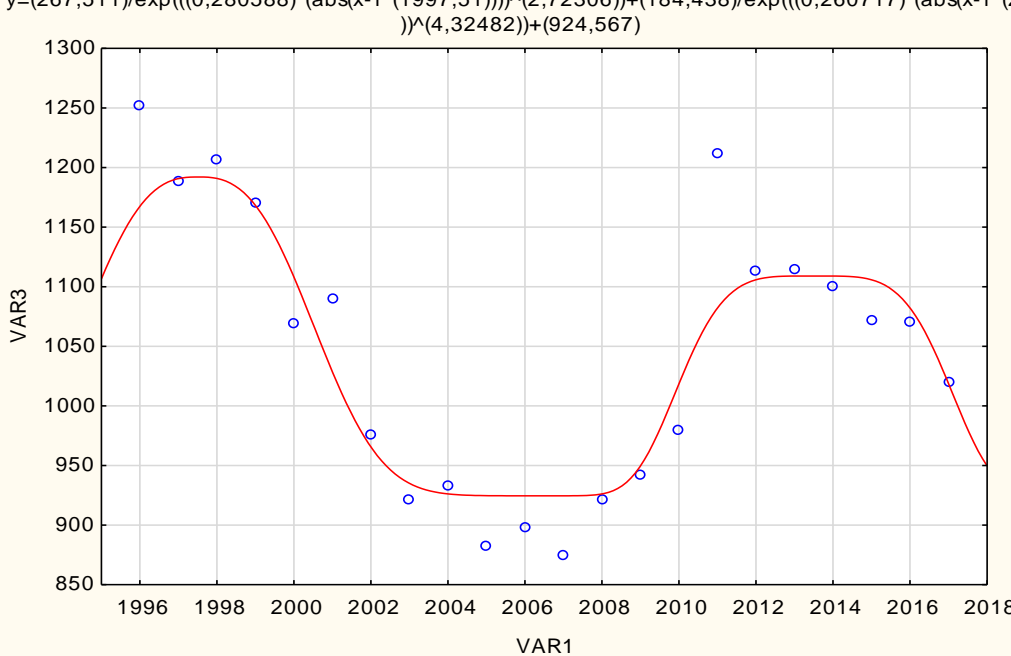

3. ábra. Nyár ABGAUÉABGAU

\begin{tabular}{|c|c|c|c|c|c|c|c|c|c|}
\hline \multirow[b]{2}{*}{$\mathrm{N}=22$} & \multicolumn{9}{|c|}{ 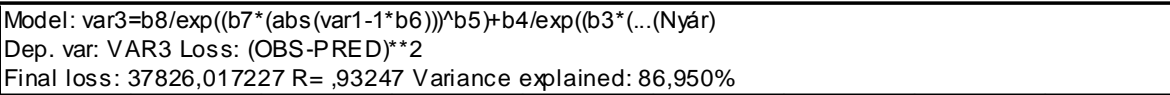 } \\
\hline & \begin{tabular}{|l|}
$\mathrm{b} 8$ \\
\end{tabular} & b7 & b6 & \begin{tabular}{l|l} 
b5 \\
\end{tabular} & $\mathrm{b} 4$ & b3 & b2 & b1 & b0 \\
\hline$\overline{\text { Estimate }}$ & $267,511 \mathrm{c}$ & $0,28058 \varepsilon$ & $1997,50 \varepsilon$ & 2,72306 & $184,438^{\prime}$ & $0,26071 i$ & $2013,49 \xi$ & 4,324825 & $924,567 i$ \\
\hline
\end{tabular}

\section{5. táblázat. Nyár ABGAUÉABGAU}

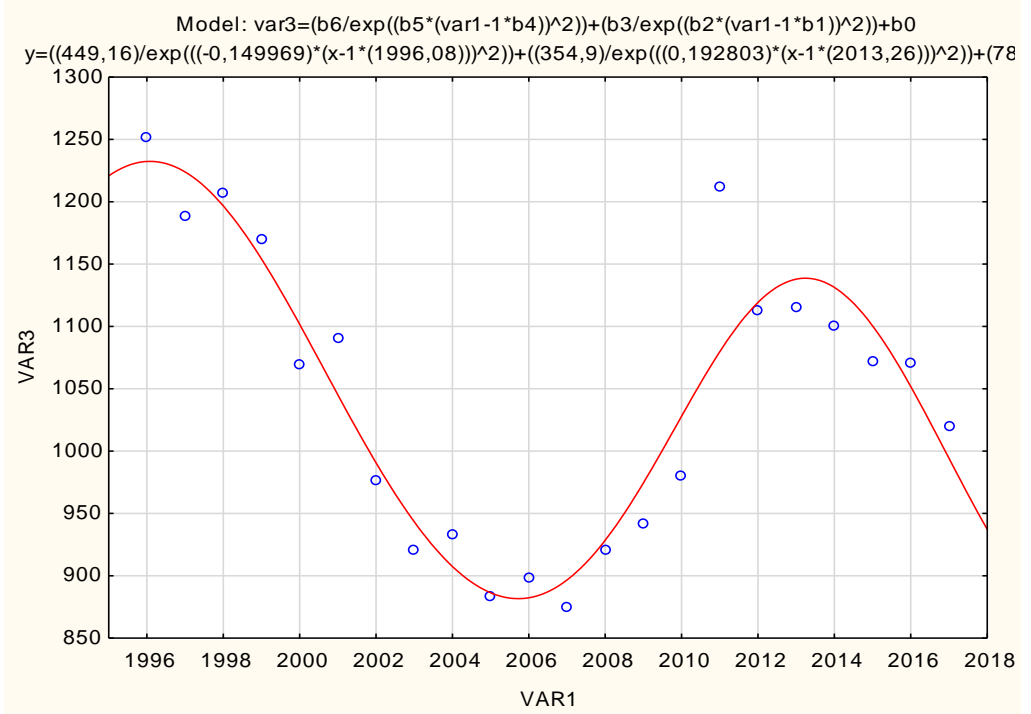

4. ábra. Nyár GAUÉGAU

\begin{tabular}{|c|c|c|c|c|c|c|c|}
\hline \multirow[b]{2}{*}{$\mathrm{N}=22$} & \multicolumn{7}{|c|}{$\begin{array}{l}\text { Model: } v \text { ar3 }=\left(\mathrm{b} 6 / \exp \left(\left(\mathrm{b} 5^{\star}(\mathrm{v} \text { ar1-1*b4)})\right)^{\star}\right)\right)+\left(\mathrm{b} 3 / \exp \left(\left(\mathrm{b} 2^{*}(\mathrm{v} \text { ar } 1 \ldots \text { (Nyár) }\right.\right.\right. \\
\text { Dep. var: VAR3 Loss: (OBS-PRED })^{\star \star} 2 \\
\text { Final loss: } 31501,971245 \mathrm{R}=, 94410 \text { Variance explained: } 89,132 \%\end{array}$} \\
\hline & b6 & b5 & b4 & b3 & b2 & b1 & b0 \\
\hline Estimate & 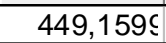 & $-0,14996 ؟$ & $1996,08 \varepsilon$ & $354,899 \epsilon$ & $0,19280 \AA$ & 2013,25 ؛ & 783,235 \\
\hline
\end{tabular}

6. táblázat. Nyár GAUÉGAU 
Model: $\operatorname{var} 4=\mathrm{b} 8 / \exp \left(\left(\mathrm{b} 7^{*}\left(\mathrm{abs}\left(\operatorname{var1} 11^{*} \mathrm{~b} 6\right)\right)\right)^{\wedge} \mathrm{b} 5\right)+\mathrm{b} 4 / \exp \left(\left(\mathrm{b} 3^{*}\left(\mathrm{abs}\left(\operatorname{var} 1-1^{*} \mathrm{~b} 2\right)\right)\right)^{\wedge} \mathrm{b} 1\right)+\mathrm{b} 0$

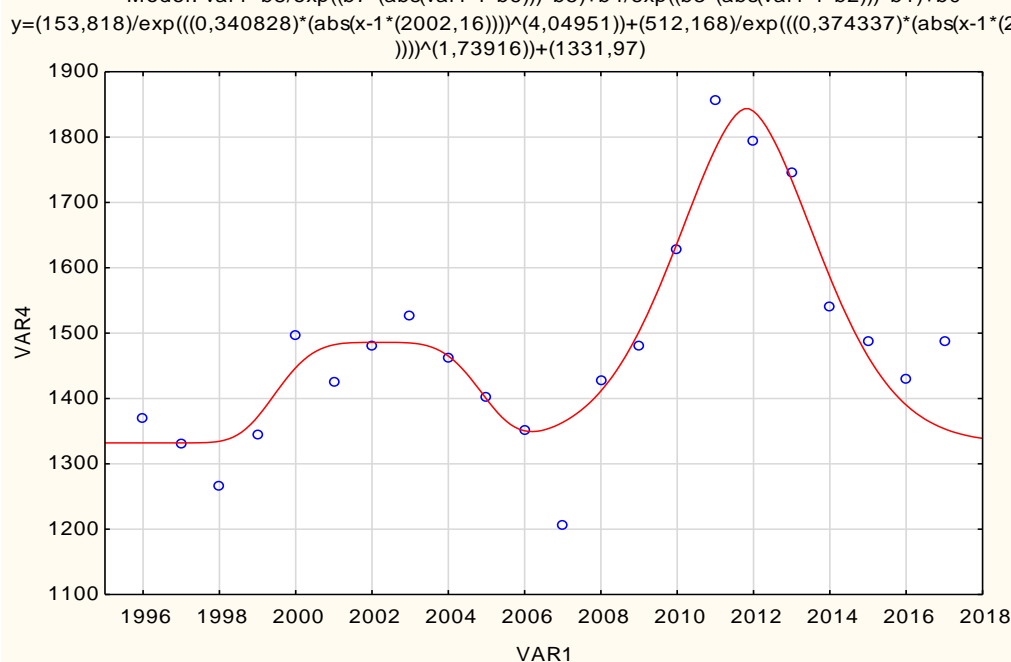

5. ábra. Akác ABGAUÉABGAU

\begin{tabular}{|c|c|c|c|c|c|c|c|c|c|}
\hline \multirow[b]{2}{*}{$\mathrm{N}=22$} & \multicolumn{9}{|c|}{ 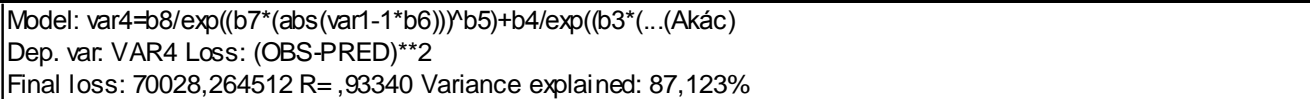 } \\
\hline & b8 & b7 & b6 & b5 & b4 & b3 & b2 & b1 & b0 \\
\hline Estimate & 153,8184 & 0,340828 & 2002,158 & 4,049508 & $512,167 \mathrm{~S}$ & 0,374337 & 2011,821 & 1,739160 & 1331,966 \\
\hline
\end{tabular}

7. táblázat. Akác ABGAUÉABGAU

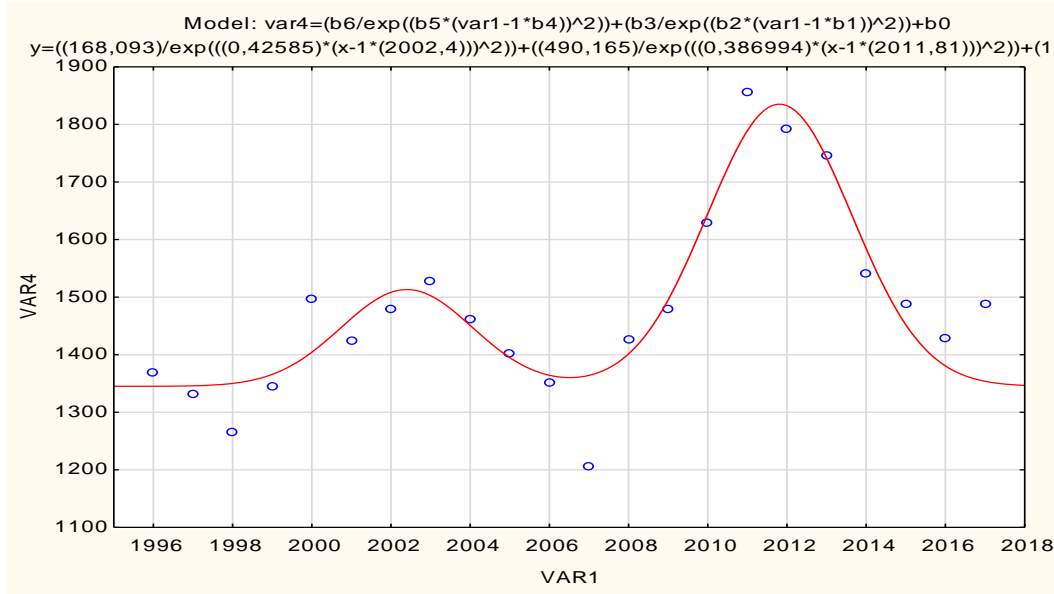

6. ábra. Akác GAUÉGAU

Model: var4=(b6/exp $\left.\left(\left(\mathrm{b} 5^{*}\left(\operatorname{var} 1-1^{*} \mathrm{~b} 4\right)\right)^{\wedge} 2\right)\right)+\left(\mathrm{b} 3 / \exp \left(\left(\mathrm{b} 2^{*}(\operatorname{var} 1 \ldots\right.\right.\right.$ (Akác)

Dep. var: VAR4 Loss: (OBS-PRED)**2

Final loss: $75839,028602 \mathrm{R}=, 92766$ Variance explained: $86,054 \%$

\begin{tabular}{|c|c|c|c|c|c|c|c|}
\cline { 2 - 8 } $\mathrm{N}=22$ & $\mathrm{~b} 6$ & $\mathrm{~b} 5$ & $\mathrm{~b} 4$ & $\mathrm{~b} 3$ & $\mathrm{~b} 2$ & $\mathrm{~b} 1$ & $\mathrm{~b} 0$ \\
\hline Estimate & 168,092 & 0,42585 & 2002,40 & 490,164 & 0,38699 & 2011,80 & 1345,10 \\
\hline
\end{tabular}

8. táblázat. Akác GAUÉGAU 


\subsection{Az erdőtelepítési adlatsorok regressziós eredményei}

Mind a két erdőtelepítési adatsor esetén az illesztési sorrend változatlan (2.1)

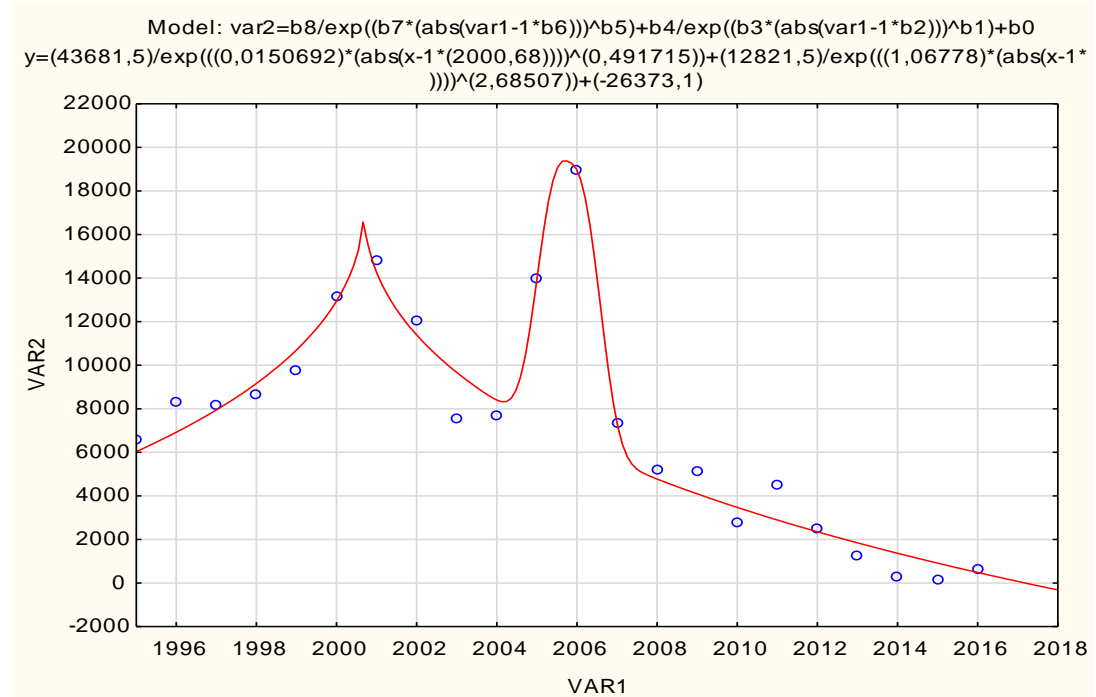

7. ábra. Első telepítés ABGAUÉABGAU

\begin{tabular}{|c|c|c|c|c|c|c|c|c|c|}
\hline \multirow[b]{2}{*}{$\mathrm{N}=22$} & \multicolumn{9}{|c|}{$\begin{array}{l}\text { Model: var2=b8/exp }\left(\left(b 7^{*}\left(\operatorname{abs}\left(\operatorname{var} 1-1^{*} \mathrm{~b} 6\right)\right)\right)^{\wedge} \mathrm{b} 5\right)+\mathrm{b} 4 / \exp \left(\left(\mathrm{b} 3^{*}(\mathrm{a} \ldots \text { (Fásitás })\right.\right. \\
\text { Dep. var: VAR2 Loss: (OBS-PRED }{ }^{\star *} 2 \\
\text { Final loss: } 15386487,604 \mathrm{R}=, 98577 \text { Variance explai ned: } 97,174 \%\end{array}$} \\
\hline & b8 & b7 & b6 & b5 & $\mathrm{b} 4$ & b3 & b2 & b1 & b0 \\
\hline Estimate & 43681,49 & 0,015069 & 2000,683 & 0,491715 & 12821,50 & 1,067781 & 2005,798 & 2,685068 & $-26373,1$ \\
\hline
\end{tabular}

9. táblázat. Első telepítés ABGAUÉABGAU

Model: $\left.\operatorname{var} 2=\left(\mathrm{b} 6 / \exp \left(\left(\mathrm{b} 5^{*}\left(\operatorname{var} 1-1^{*} \mathrm{~b} 4\right)\right)\right)^{\wedge} 2\right)\right)+\left(\mathrm{b} 3 / \exp \left(\left(\mathrm{b} 2^{*}\left(\operatorname{var} 1-1^{*} \mathrm{~b} 1\right)\right)^{\wedge} 2\right)\right)+\mathrm{b} 0$

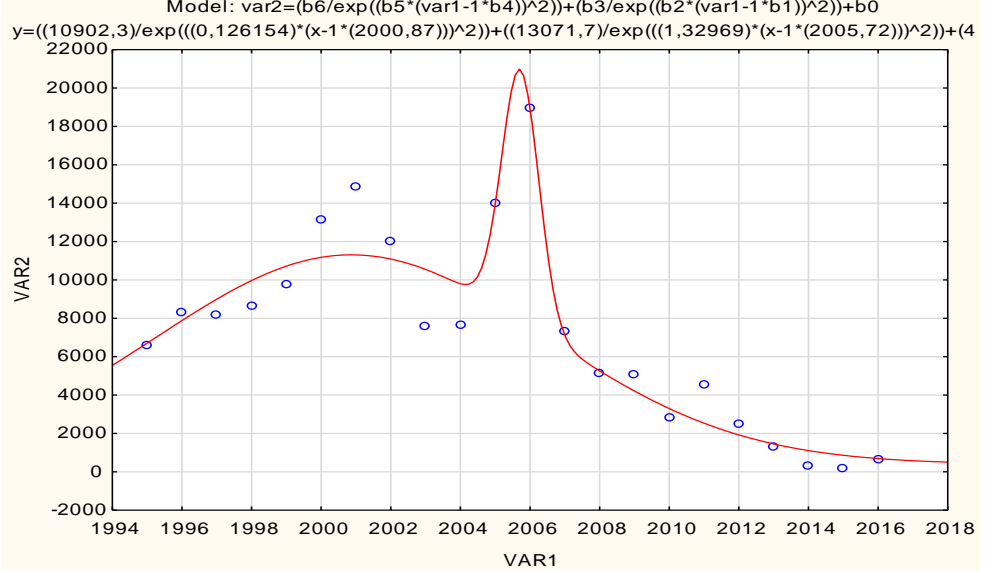

8. ábra. Első telepítés GAUÉGAU

\begin{tabular}{|c|c|c|c|c|c|c|c|}
\hline \multirow[b]{2}{*}{$\mathrm{N}=22$} & \multicolumn{7}{|c|}{$\begin{array}{l}\text { Model: var2 }=\left(\mathrm{b} 6 / \exp \left(\left(\mathrm{b} 5^{*}\left(\operatorname{var}_{1-1}{ }^{*} \mathrm{~b} 4\right)\right)^{\wedge} 2\right)\right)+\left(\mathrm{b} 3 / \mathrm{exp}\left(\left(\mathrm{b} 2^{*}(\text { var1 } \ldots \text { (Fá sítás })\right.\right.\right. \\
\text { Dep. var: VAR2 Loss: }(\mathrm{OBS}-\mathrm{PRED})^{\star \star} 2 \\
\text { Final loss: } 40639234,125 \mathrm{R}=, 96196 \text { Variance explained: } 92,536 \%\end{array}$} \\
\hline & b6 & b5 & b4 & b3 & b2 & b1 & b0 \\
\hline Estimate & 10902,3 & 0,12615 & 2000,86 & 13071,7 & 1,32969 & 2005,72 & 405,569 \\
\hline
\end{tabular}

10. táblázat. Első telepítés GAUÉGAU 


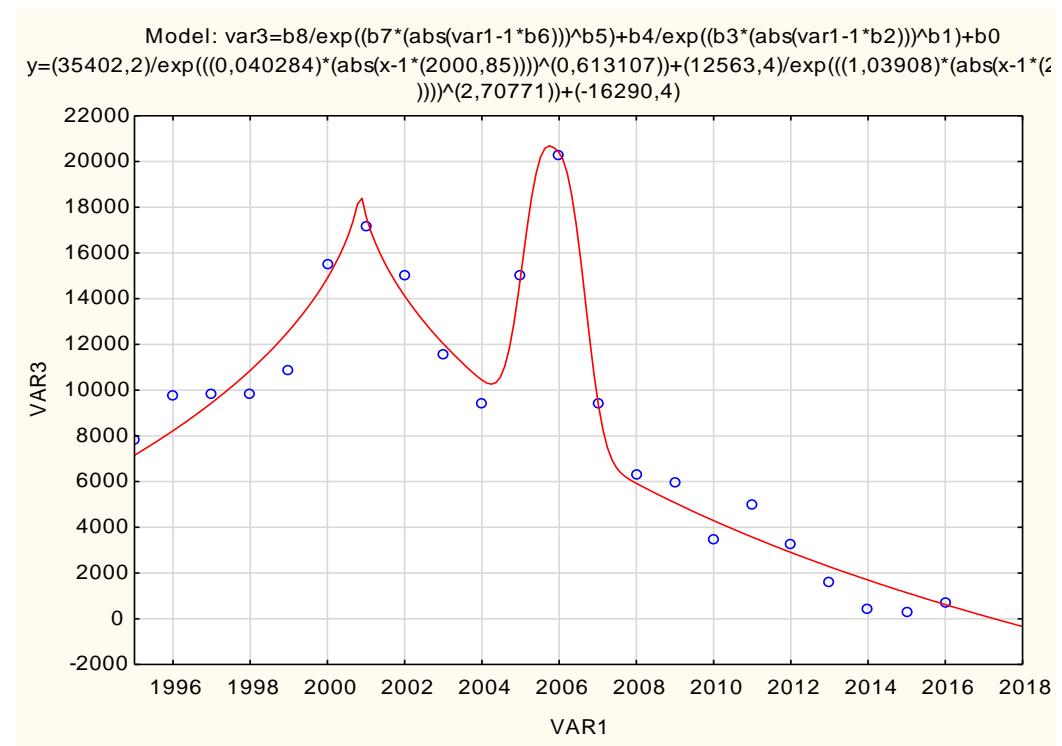

9. ábra. Összes telepítés ABGAUÉABGAU

\begin{tabular}{|c|c|c|c|c|c|c|c|c|c|}
\hline \multirow[b]{2}{*}{$\mathrm{N}=22$} & \multicolumn{9}{|c|}{ 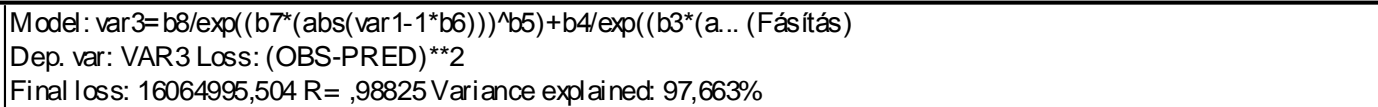 } \\
\hline & $\begin{array}{l}\mathrm{b} 8 \\
\end{array}$ & b7 & b6 & b5 & b4 & b3 & b2 & b1 & b0 \\
\hline Estimate & 35402,21 & 0,040284 & 2000,848 & 0,613107 & 12563,43 & 1,039083 & 2005,872 & 2,707708 & $-16290,4$ \\
\hline
\end{tabular}

11. táblázat. Összes telepítés ABGAUÉABGAU

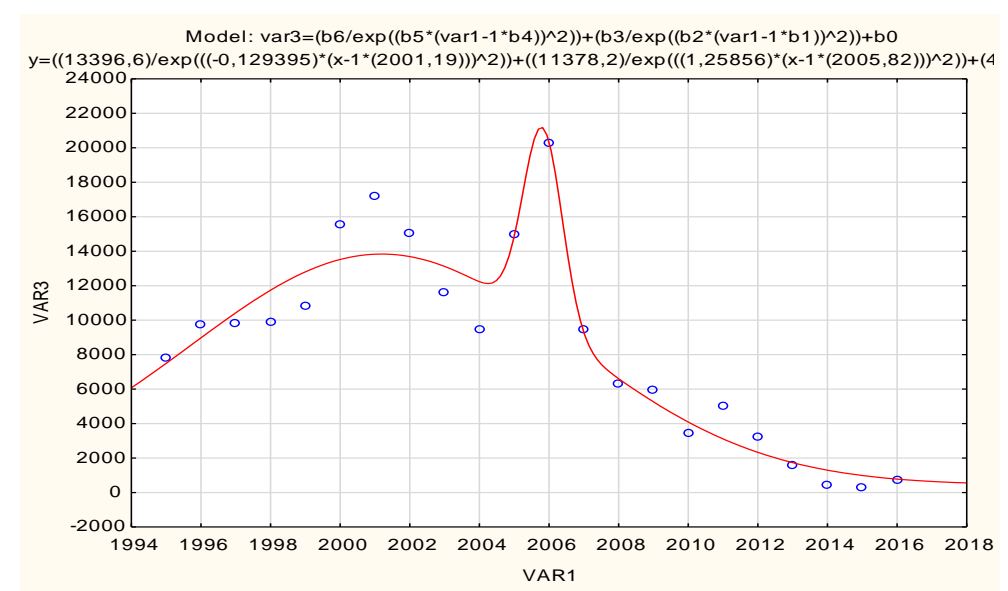

10. ábra. Összes telepítés GAUÉGAU

\begin{tabular}{|c|c|c|c|c|c|c|c|}
\hline \multirow[b]{2}{*}{$\mathrm{N}=22$} & \multicolumn{7}{|c|}{$\begin{array}{l}\text { Model: var3 }=\left(\mathrm{b} 6 / \exp \left(\left(\mathrm{b} 5^{\star}(\mathrm{v} \text { ar1-1*b4) })\right)^{\wedge} 2\right)\right)+\left(\mathrm{b} 3 / \exp \left(\left(\mathrm{b} 2^{*}(\mathrm{var} 1 \ldots \text { (Fásítás })\right.\right.\right. \\
\text { Dep. var: VAR3 Loss: (OBS-PRED })^{\star *} 2 \\
\text { Final loss: } 42254557,076 \mathrm{R}=, 96878 \text { Variance explained: } 93,854 \%\end{array}$} \\
\hline & \begin{tabular}{|c|}
$\mathrm{b} 6$ \\
\end{tabular} & b5 & b4 & b3 & b2 & b1 & b0 \\
\hline$\overline{\text { Estimate }}$ & 13396,60 & $-0,129395$ & 2001,191 & 11378,23 & 1,258563 & 2005,819 & 438,361 \\
\hline
\end{tabular}

12. táblázat. Összes telepítés GAUÉGAU 


\subsection{Elemzés, értékelés}

\section{A fakitermelési adatok regressziós vizsgálatának elemzése fafajonként:}

\section{- Tölgy}

A kapott R értékek alapján az ABGAUÉABGAU pontosabb illesztést eredményez, amit jól igazolnak az illesztési ábrák. Bár a szélsőértékek száma a két modell esetén megegyező, a pontsor követése az első esetben sokkal szorosabb.

- Nyár

A kapott R értékek alapján itt a GAUÉGAU mutat század nagyságrendben nagyobb értéket. Az ábrák vizsgálatából az tűnik ki, hogy az említett modell határozottabb lefutású a szélsőértékekre nézve, ennek oka a pontsorozat jellegéből adódik.

- Akác

A R értéke ennél a fafajnál az ABGAUÉABGAU esetében nagyobb. Bár hasonló jelleget mutat a két modell grafikonja a jobb illesztés észlelhető. A kettős Gauss esetében az egyes szélsőértékekhez tartozó hullámokat szimmetria jelzi míg a módosított kitevő esetén az asszimetria is fellelhető, ami indokolja a már említett nagyobb R értéket.

Mind a három fafaj esetében az egyes illesztések eredményeiből meghatározhatók a növekvő, csökkenő időszakok intervallumai mind a független mind a függő változóra, meghatározhatók a szélsőérték helyek és értékek. Az ábra alapján közelítőleg a modell alapján pontosan megadhatók az inflexiós helyek és értékek, melyek a változási sebesség meghatározó pontjai, valamint megadják a modell konvex illetve konkáv intervallum határait.

\section{Értékelés:}

A felsoroltak igazolják, hogy az alkalmazott modellek hasonló jellegü adatsorok vizsgálatára alkalmasak, könnyen használhatók és részletes tájékoztatók.

\section{Az erdőtelepítési adatok regressziós vizsgálatának elemzése telepítési típusonként:}

- Első telepítés

$\mathrm{Az}$ adatsor értékeinek jelentős ingadozását itt az ABGAUÉABGAU modell követi kellő pontossággal, amit a $\mathrm{R}=0,9857$ érték is fémjelez, míg ugyan magas $\mathrm{R}$ értéket jelez a GAUÉGAU modell $\mathrm{R}=0,9619$ a pontsorozat követése ennél azonban lényegesen pontatlanabb.

- Összes telepités

Az adatsor hasonló jellegü az első telepítés adatsorához. Az eredmény itt is azt mutatja, hogy az ABGAUÉABGAU modell rugalmasan követi a pontsorozatot, amit alátámaszt az R érték, ami itt eléri a 0,9882-t. A kettős Gauss követési pontossága lényegesen gyengébb még az $\mathrm{R}=0,9687$ magas értéke ellenére is.

\section{Értékelés:}

A fenti adatsorok igazolják a két modell közötti jelentős rugalmassági tulajdonsági eltérést. Bizonyos esetekben lehet elegendő a kettős Gauss alkalmazása is, ha eltekintünk az adatsor erős szóródásától, viszont ekkor a folyamat leírása pontatlanná válik. Ezzel szemben a módosított kitevő révén kapott modell kellő pontossággal írja le a folyamatot 


\section{3. Összefoglaló}

A gyakorlati életböl, az erdészet területéről választott adatsorok nem hasonlíthatók egy klasszikus fizikai, kémiai mérési sorozathoz, ahol a tendencia várható, a mért értékek szélsőséges ingadozása nem jellemző. Az itt vizsgált adathalmazok változékonyak, több maximum vagy minimum értékkel bírhatnak, növekedési vagy csökkenési sebesség változása mellett. Jellemzésükre nem alkalmasak a hagyományos egyszerü modellek. A bemutatott két modell, a kettős Gauss GAUÉGAU valamint a kitevőkben módosított ABGAUÉABGAU rendelkezik azzal a rugalmassággal melyre az illesztésnél szükség lehet.

Az eredmények igazolják, hogy különösen az utóbbi függvény alkalmas ehhez hasonló szélsőséges adatsorok jellemzésére megfelelő pontossággal. A függvény jól mutatja az adathalmaz szakaszainak menetét, szélsőértékeit, konvexitását, inflexiós pontjait, ugyanekkor magas korrelációs értéke jelzi az illesztés pontosságát. Mindez indokolja a függvény alkalmazását szélsőséges adatsorok esetén.

\section{Irodalomjegyzék}

[1] Csanády V., Horváth-Szováti E., Szalay L., Alkalmazott statisztika, Sopron, Nyugat-Magyarországi Egyetem Kiadó (2013), 175p.

[2] Központi Statisztikai Hivatal. https://www.ksh.hu/stadat . 